\title{
Factors Influencing Occupational Segregation by Gender in Malaysia
}

\author{
Noor Rahamah Abu Bakar ${ }^{1}$ \\ ${ }^{1}$ Faculty of Social Science and Humanities, Universiti Kebangsaan Malaysia, 43600 UKM Bangi, Selangor Darul \\ Ehsan, Malaysia \\ Correspondence: Noor Rahamah Abu Bakar, Faculty of Social Science and Humanities, Universiti Kebangsaan \\ Malaysia, Selangor Darul Ehsan, Malaysia
}

Received: August 12, 2014

Accepted: August 26, 2014

Available online: September 4, 2014

doi:10.11114/ijsss.v2i4.507

URL: http://dx.doi.org/10.11114/ijsss.v2i4.507

\begin{abstract}
In many developing countries, occupational segregation by gender is a topic that is much discussed but very few researches had been carried out. In Malaysia, secondary sources of data, such as the Population and Housing Census reports and Social Statistics Bulletins of the Malaysian Statistics Department do show that there have been some changes in the general trends of occupational segregation in the country but factual details of occupational segregation based on gender are rather scanty. This paper seeks to throw some lights on this subject of occupational segregation by presenting findings of a micro study conducted in a village in the district of Seremban, Negeri Sembilan Malaysia, involving a sample of 12 families. Analyses of the primary data had pointed out six factors that influenced occupational segregation, that is, formal education and training, the division of labour in the household, culture of local Malay society, working conditions, facilities at the work place is not woman friendly, and individual preferences in terms of taste, property and talent. The micro findings lead to the conclusion of three ways whereby not only working women may be empowered to widen their career paths but also that the division of work by gender may be simultaneously reduced. These are the introduction of more woman friendly procedures in the work place, the re-organization of work that seeks to demolish traditional identification of occupations with gender, and the improvement of education and training policies that would enable women to climb the occupational ladder.
\end{abstract}

Keywords: division of work, horizontal segregation, occupational segregation, re-organization of work, vertical segregation, women friendly

\section{Introduction}

The concentration of female and male workers is different according to the type of industry and occupational categories. Macro data showed that in 2005 female workers are concentrated in the community service, social and private industry, and finance, insurance \& service property business industry respectively while male workers in mining \& quarrying, and construction industry. If examined from the perspective of occupational categories, the focus on women workers are in the clerical and professional fields such as teachers and nurses while male workers in the field of administration \& management employment, and agriculture. At the micro level, observation is being made concerning woman's opinion regarding suitable job that is appropriate for them. The result of the macro findings is similar to the micro information, whereby jobs tend to be done by women is as educators, doctors and clerks. However, the macro data showed that the horizontal and vertical occupational segregation still exist in Malaysia. This paper tries to explain the factors that influenced occupational segregation by gender.

\section{Methodology and Study Area}

This study involved data collection and analysis at two levels, which is macro and micro. Collection of secondary data is from the Population and Housing Census published by the Malaysian Department of Statistics for the years 1970, 1980, 1991 and 2003. Only the Population and Housing Census can provide information about the long term changes in the employment patterns by gender. At the macro level, data and information are gathered to identify the distribution of employment by gender in the industry and major occupational categories. At the micro level, a survey was conducted in a village to obtain primary data. For sample selection, a purposive sampling method was used. Selections of 12 families or 36 respondents were done at the initial level. Selected families include family unit that has three generations regardless of whether a nuclear or extended family. Second generation was selected as the main sample obtained in accordance with the highest education attainment. All the families were selected using the technique of 'snowball'. 
Researchers asked individuals to identify those that fulfil the characteristics of being selected as respondents. Apart from the questionnaires, interviews directly with respondents were carried out to obtain clear and accurate information. Secondary data obtained from the Department of Statistics and primary data from fieldwork was analyzed using the manual method. Descriptive statistics were also used to fulfil the purpose of this paper.

\section{The Findings}

Information and data obtained from the macro and micro study showed that there are six factors affecting occupational segregation by gender, that is (i) formal education and training, (ii) the division of labour in the household, (iii) culture of local Malay society, (iv) working conditions, (v) facilities at the work place is not 'women friendly', and (vi) individual preferences in terms of taste, priority and talent.

\subsection{Formal Education and Training}

Education and training factors explained the differences in terms of the stream of study selected according to gender. Women and men are given the same opportunity of formal education, but women gain, low work experiences because their own work duration in the labour market is less than male workers (Joseph, 1983). Therefore, the women workers earn lower wages. A decision made by women not to work continuously in the labour market is caused by the perception of the society about women's responsibility to the family. Women gained familiarity and beliefs about their role that is more accountable to the family, especially looking after the children that are still small. There is a respondent from the second generation that had taken a long break in the work to take care of her child who was admitted in the hospital. Children feel more comfortable if taken care of by the mother compared to their father or other family members (Noor Rahamah, 2009). Thus, employment in the secondary sector with lower income and is in the low hierarchy in the organization is suitable with women who decide not to work continuously in the labour market.

Level of education attained by gender is almost equal, but women have less human capital in terms of work experiences because they have less work duration than men (Blau \& Jusenius, 1976). The equality of the work force supplied is different due to the different distribution patterns of the labour market. Women participate in jobs that require little or no work experiences such as maids, cooks and waiters. The women expect to face with the responsibility of the family. As such, they take jobs that do not suffer loss if stopped from working at any time. The effect of this action, women that expect to stop temporarily from participating in the labour market to care for the children will limit human capital investment.

In the writer's opinion, women and men need different number and type of skills. In terms of skills, for example, women and men need long general training programs, such as nurses and architects. In addition, there are jobs which require specialized training such as company secretary and administrative assistant. There is also employment entered into by both genders which requires less work skills such as waiter/waitress and building cleaners. The issue is that women and men who participate in employment have their own skill and there are jobs that are more suitable for women only. To clarify this issue, respondents interviewed stated that they have low skill and participate in employment to increase the family income. In addition, they are from the poor family, who do not have enough money to pay for their children's education fees and to attend skill training programs. The explanation made it clear that formal education, training and work experience is very important to get a job as describe by Becker (1975) in the human capital theory, but the choice of educational stream specifically at upper secondary level influences the selection pattern of a job.

Apart from formal education and training factor raised by Walby (1988), there are also other factors that affected the concentration of women in certain occupations (Figure 1).

\subsection{The Division of Labour in the Household}

Problems faced by women in the labour market can be seen from their responsibilities for housework and child care. This ideology greatly affects the kind of work suitable taken up by women as well as their ability to participate in employment in the modern sector. Furthermore, the level and type of education received is determined by their future roles as mothers and wives. For working mothers, two basic problems can be identified. Firstly, child care while they go out to work and secondly the 'second shift' they faced when returning home after work and performing household duties.

Micro study showed that women who work depend on the mother, mother-in-law and friends to care for their children during working hours (Table 1). Only one third generation respondent who received assistance from the maid and still staying with her parents. There is one respondent from the second generation that work and send her young children to the mother's house nearby. Micro data also showed that 4 respondents from the third generation get help from maid, mother-in-law and friends to take care of the kids while the husband and wife are out working. 


\begin{tabular}{|l} 
Personal and \\
Demographic factors: \\
Formal education level \\
$\circ \quad$ primary level \\
$\circ \quad$ secondary level \\
$\circ \quad$ tertiary level \\
Formal training \\
$\circ \quad$ specific \\
$\circ$ general \\
Division of labour \\
in the household \\
$\circ$ home tasks \\
$\circ$ purchase of goods \\
$\circ$ age of children \\
$\circ$ number of children \\
$\circ$ forms of childcare \\
$\circ$ nucleus/extended family \\
Individual preferences \\
\end{tabular}

\section{Employment concentration}

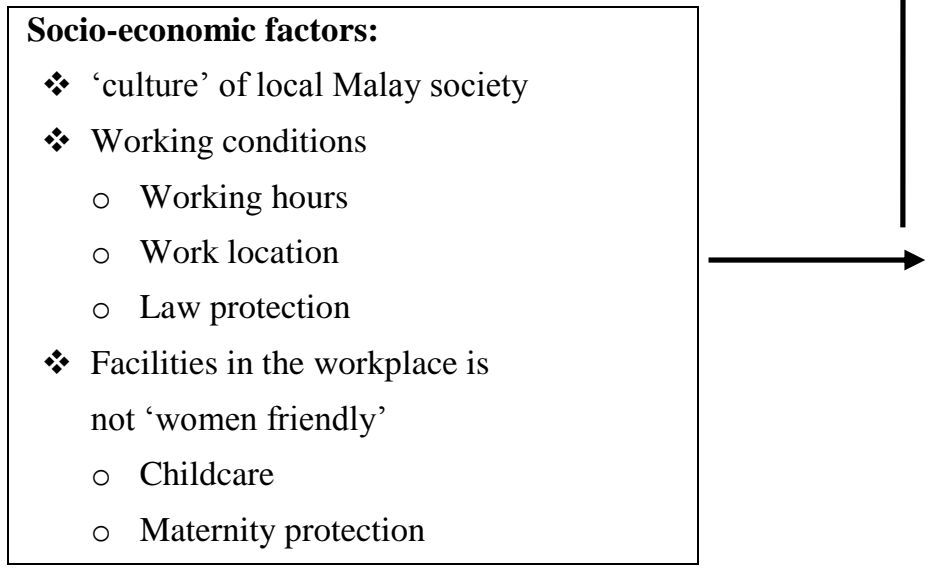

Figure 1. Factors affecting the concentration of women in certain occupations

Table 1. Child care for working mothers by generation $(n=6)$

\begin{tabular}{lcccccc}
\hline & \multicolumn{2}{c}{ First generation } & \multicolumn{2}{c}{ Second generation } & \multicolumn{2}{c}{ Third generation } \\
& No. & \% & No. & \% & No. & \% \\
\hline Mother & - & - & 1 & 50.0 & - & - \\
Mother-in-law & - & - & - & - & 1 & 25.0 \\
Maid & - & - & 1 & 50.0 & 1 & 25.0 \\
Friends & - & - & - & - & 2 & 50.0 \\
Total & 0 & 0 & 2 & 100.0 & 4 & 100.0 \\
\hline
\end{tabular}


When interviewing several first generation respondents, they expressed that they are more comfortable choosing to look after their grandchildren than giving to the maid or sent to kindergarten or nursery. Two third generation respondents stated that they trust more of their children taken care of by a friend than being sent to the child care centre. Nurseries take a big number of children and individual care cannot be done properly. In general, it was found that changes in family structure and female employment patterns give support to family members to take care of kids and this can help mothers who want to participate in formal employment.

How with the help of the husband? Empirical data showed that the husband does a little house duty, while at the same time increased the workload of the wife. However, there are signs of change in the family. The men now want to help their wives doing household tasks such as washing clothes, washing dishes and cleaning the house, in which the alternative assistance from other members of the family could not be obtained (Noor Rahamah \& Mohd. Yusof, 2013). Analysis showed that 3 respondents, respectively 2 and 1 of the second and third generations, whereby the husband assist in performing household tasks. For example, the husband of the second generation respondent who is a pensioner and formerly worked as a clerk whiles the third generation respondent's husband was working as an accountant. Accordingly, the ability of women to participate in paid work is subject to the availability of facilities to care for their children and husband's attitude towards her responsibilities.

It is the practice in Malaysian society which views men as head of household and is responsible for the expenses of the family. With these, women are seen as dependent on her husband, stayed at home to manage the household and take care of the children. According to the first generation respondents in this study, there is no need for them to be engaged in formal employment as they are married. The point here, they already have a husband to support them. View of the husband as the bread winner for the family had been refuted by some respondents from the third generation. One of the respondents who work as an auditor and have a husband who work as an assessment officer noted that women also have an obligation to her family. Working women either unmarried or married contribute to their families (Table 2). Indirectly, this contribution will improve their family life. Myths such as woman staying at home and husband as a breadwinner is less appropriate in the modern world because it can influence government labour policies and family decision on education and training. Micro studies also showed that women hold to the Malay proverb, " prepare an umbrella for the rainy days". They keep part of the saving to face hard times that cannot be expected. In addition, the cost of children's education expenses is high and this rise awareness for women to work to supplement the family income.

Table 2.Usage of respondents monthly income* $(n=16)$

\begin{tabular}{lccc}
\hline & $\begin{array}{c}\text { First generation } \\
\mathbf{n = 1}\end{array}$ & $\begin{array}{c}\text { Second generation } \\
\mathbf{n = 7}\end{array}$ & $\begin{array}{c}\text { Third generation } \\
\mathbf{n = 8}\end{array}$ \\
\hline Contribution to family & - & 5 & 8 \\
Expenses for own use & - & 3 & 6 \\
Transportation expenses & - & 3 & 3 \\
Saving & - & 6 & 6 \\
Payment for educational loan & - & - & 1 \\
Daily expenses & - & 1 & 1 \\
Expenses for children & - & - & 1 \\
No answer & 1 & 1 & - \\
\hline
\end{tabular}

Note: * the answer is more than one

From another perspective of the household division of labour, tasks which are always done at home affect the type of work selected in the labour market. In the early stage, parents have a different attitude towards the role of the daughters and sons in doing household tasks. According to some respondents from the second generation, they have educated their daughters aged seven years old of how to cook, wash clothes, wash dishes, cleaning the house and taking care of younger siblings. A different perception takes place for the son. At the same age, boys are busy playing football with their friends. Different views shown by the parents of the role of daughters and sons continued until the time of the selection of the appropriate type of employment for them. Parents see the job suitable for their daughters are those associated with the work done at home. The stereotypical view should be scraped off so that the division of labour by gender can be reduced.

\section{3 "Culture" of Local Malay Society}

Cultural factor in this context refers to the norms of the society itself. Sixteen respondents who have and still work explained that Malay women workers cannot interact with the man who has no family relationship. Other reasons that prevent the movement of women in certain occupations is associated with the role of women in childbirth and the 
traditional view of the surrounding society. The macro study found that women are more likely to enter employment in the field of humanities or social science due to their exposure in this field since childhood (Aminah Ahmad, 2000).

The type of work chosen by women also provides them with low salaries. Therefore, they had to work harder by working overtime. Limited attention towards household tasks also makes family suffer. Children do not have the opportunity to be close to their working mothers and they have no room to voice their problems. The general view of the society also showed that woman is more suitable to stay at home. Women will suffer loss, especially the poor compared with those in the middle class. Statistics showed that monthly poverty line income per household in Malaysia in 2004 is RM691. Husband's income as "breadwinner" was insufficient to support the family. Average household income stood at RM3249 for the same period (Malaysia, 2006). Thus, a change of view should exist that can support and give confidence to women to go out to work; at least this can help the family to improve their quality of life.

\subsection{Working Conditions}

Based on international standards, working hours is not more than forty-eight hours a week. For working women, they have to divide between working hours with time managing household tasks such as child rearing and housework. These two duties burden the working women. That is why many women choose jobs that provide comfort such as fixed working hours, easy accessibility and simple work regulations. These can be seen in the following explanation.

Micro study results showed that 15 of 16 respondents that have been and still work choose jobs which have fixed working hours and working for eight hours a day. Work location is also an important factor when seeking to engage in formal employment. Half of the respondents who have been and still working have their workplace which is within five miles of the place of residence.

Another aspect that has important implications for working women is the law protection. This includes work rules that prohibit women from working in the industry at night, work involving heavy lifting or other work that is considered dangerous to health. These rules are in accordance with the Employment Act, 1955 (Act 265). Although Section 34 of the 1955 Act states that it restricted a female employee to work between the hours of $10.00 \mathrm{pm}$ and $5.00 \mathrm{am}$ in an industry, but the Ministry may give an exemption. For example, under the work rules female conductor 1958, a female employee may work between 10.00 at night and 1.00 am on the following day. Regulations for women working according to shifts enacted in 1970 as approved by the Minister, they can work during the day between 9.00 am to 5.00 $\mathrm{pm}$ and in the evening between $10.00 \mathrm{pm}$ to $5.00 \mathrm{am}$.

In addition, every female employee is entitled to maternity leave for a period of 60 consecutive days for each confinement and eligible for as many as five times during the service. Leave and maternity allowance is paid entirely by the employer. According to the Employment Act, a woman can start maternity leave within 30 days before delivery. However, a woman can apply to commence maternity leave at any time within 14 days before delivery if approved by the doctor.

\subsection{Facilities at The Work Place is not 'Women Friendly'}

Facilities at work place that is 'women friendly' such as providing infant and child care and suitable maternity leave period is important to allow women to work in peace. The increase in the number of female employees having young children and their parent's awareness about the importance of the preschool, the child care services and facilities are essentials. Findings from micro studies showed that women who work depends on the mother, mother-in-law, maids and friends to care for their children during the time they go out working. They feel uncomfortable to send their children to day care or preschool that are operated by the private sector and located in a residential area away from their work place. Thus, it makes more sense if the nursery and kindergarten are built near work places and operated by the employers themselves. This will facilitate the parents to monitor their children during work breaks and can suppress calm feelings associated with well-being of their children.

Aside from child care facilities, maternity protection is also a matter of importance for working parents. According to the Employment Act 1955, every female employee is entitled to maternity leave for a period of not less than 60 days (8 weeks) in a row. However, the length of maternity leave in Malaysia is very short compared with western countries such as Australia (52 weeks), United Kingdom (40 weeks), and Norway (28 weeks) (Organisation for Economic Cooperation and Development, 1994). To facilitate the wife to care for herself and her child after birth, the husband is given a seven-day holiday. However, the writer felt that the leave granted is not enough.

\subsection{Individual Preferences in terms of Taste, Priority and Talent.}

Individual preferences in this context refer to taste, priority and talent. In the opinion of the writer, taste, priority and talent factors should be taken into consideration as had been found in this study as well as that had been said by Blau and Jusenius (1976), Sinclair (1991) and Walby (1997). For example, a woman chooses job A that gives a lower salary than job B because she likes and interested in job A. The society in general does not restrict the freedom of women to 
make their own decision. The woman's decision to become a secretary or a nurse and not a surveryor or technologist is seen as a personal preference. This description can be clearly demonstrated in the micro study where 37.5 percent of respondents indicated that they prefer a particular job because they like the job. This taste factor may also reflect the socialization process of women.

Study at micro level also found that many women are in the category of low wage jobs and do unskilled work such as employment in clerical and services. Things happening is clearly described in the dual labour market theory introduced by Barron and Norris in 1976. According to this theory, women workers are always in the secondary sector which provide low wages, focused in unskilled jobs and will be terminated earlier than male workers. A woman would rather do jobs for which they can apply to when they resign at any time. They prefer jobs such as a typist and maid. Male workers are concentrated in the primary sector, the jobs which require skill, high wage and the opportunity to advance their career, such as architects, engineers, surveyors, managers and field supervisors.

\section{Conclusion}

The discussion in this paper relates to the factors that influenced the segregation of employment by gender. Formal education and job training obtained by women are important in determining their concentration in certain types of employment. However, this idea must touch on the early stages of education and also at the advanced level. Findings from this study indicated that education in both levels is very important when you want to discuss human capital in the labour market. The number of women in the labour market in 2005 had increased compared with 45 years ago. Achievements in the field of education had increased and enable them to enter a particular field of employment. However, formal education and work training received is not enough to explain precisely about why women are concentrated in certain jobs, even though in terms of educational attainment is almost equal to men.

Why is this happening? If examine the dual labour market theory by Barron and Norris, there is an explanation for the concentration of women workers in the secondary sector and male workers in the primary sector. Women workers were given low wages and do work that do not require skills. The basic job qualification entry is just formal education. To enable women to be at a higher level in the organization ladder or can do the job in the primary sector, they must be willing to attend training related to their job. With low levels of education received by women, and are not interested in obtaining job training and have low interest to obtain higher wages will cause them to do low status jobs.

The findings of this study indicated that apart from the formal education and work training, there are also other factors that influenced the distribution of occupational segregation by gender. Micro study showed that the division of labour in the household, culture of local Malay society, working conditions, facilities at the work place is not 'women friendly', and individual preferences in terms of taste, priority and talent influenced the concentration of women in certain types of employment. There are three ways to enable female workers to be involved in the field they want to venture into and at the same time can reduce the occurrence of division of labour by gender, that is, establishing regulations in the workplace that is "women friendly", reorganizing of work and to improve the education and training policies.

\section{References}

Aminah, A. (2000). The participation of Malaysian women in education: the post-independence era. Kertas kerja The $16^{\text {th }}$ Conference of the International Association of Historians of Asia. Kota Kinabalu, Sabah, 27-31 Julai.

Barron, R.D., \& Norris, G.M. (1976). Sexual divisions and the dual labour market. Dlm. Beechey, The changing experience of women, hlm. 9-13. Milton Keynes: Open University Press.

Becker, G. S. (1975). Human capital: a theoretical and empirical analysis, with special reference to education. Ed. ke-2. Chicago: The University of Chicago Press.

Blau, F.D., \& Jusenius, C. L. (1976). Economists' approaches to sex segregation in the labor market: an appraisal. Dlm. Blaxall, M. \& Reagan, B. (pnyt.). Women and the workplace: the implications of occupational segregation, hlm.187-188. Chicago: The University of Chicago Press.

Bouffartigue, P. (2010). The gender division of paid and domestic work: some remarks in favour of a temporal perspective. Time \& Society 19 (2): 220-238. http://dx.doi.org/10.1177/0961463X09337855

Fuwa, M., \& Tsutsui, J. (2010). A cross-national comparison of the perceived fairness of the division of household labour. Japanese Journal of Family Sociology, 22, 52-63. http://dx.doi.org/10.4234/jjoffamilysociology.22.52

Joseph, G. (1983). Women at work: the British experience. Oxford: Philip Allan Publishers Limited.

Malaysia. (1970). Population and Housing Census of Malaysia, 1.

Malaysia. (1980). Population and Housing Census of Malaysia, $1 \& 2$.

Malaysia. (1991)(a). Sixth Malaysia Plan1991-1995. 
Malaysia. (1991) (b). Population and Housing Census of Malaysia, $1 \& 2$.

Malaysia. (1995). Seventh Malaysia Plan 1996-2000.

Malaysia. (2001). Eighth Malaysia Plan 2001-2005.

Malaysia. (2003). Population and Housing Census of Malaysia: economic characteristics of the population.

Malaysia. (2006). Ninth Malaysia Plan 2006-2010.

Malaysia. (2010). Tenth Malaysia Plan 2011-2015.

Nameda, A. (2011). Fairness in the division of family work: understanding the sense of entitlement in interpersonal contexts. Japanese Journal of Family Sociology, 11, 58-76. Els/110009687852

Nameda, A. (2013). Sense of fairness in the division of labour in close relationship: procedure and gender role ideology. Japanese Psychological Research, 55, 33-44. http://dx.doi.org/10.1111/j.1468-5884.2012.00539.x

Noor Rahamah Hj. Abu Bakar. (1995). Wanita bekerja dan keluarga. Dlm. Mostafa Kamal Mokhtar, Noor Rahamah Hj. Abu Bakar, Ong Puay Liu \& Suhaimi Salleh (pnyt.). Karya Darma ll: Kemanusiaan dalam pembangunan, hlm, Bangi: Penerbit Universiti Kebangsaan Malaysia, 37-53.

Noor Rahamah Hj. Abu Bakar. (2009). Wanita bekerja dan penjagaan anak. Dlm. Aishah@ Esah Haji Mohamad, Sulong Mohamad, Zaidah Mustapha \& Rokiah Ismail (pnyt.). Peranan, Hak dan Penyesuaian Hidup Wanita di Malaysia, hlm. 14-22. Bangi: Pusat Pengajian Sosial, Pembangunan dan Persekitaran, FSSK, UKM.

Noor Rahamah Abu Bakar \& Mohd. Yusof Abdullah. (2013). The sustainability of dual earner at the workplace in Malaysia. Asian Social Science Journal, 9(7), 192-199. http://dx.doi.org/10.5539/ass.v9n7p192

Organisation for Economic Co-operation and Development. (1994). Women and structural change: new perspectives. Paris: OECD.

Schneider, D. (2012). Gender deviance and household work: the role of occupation. American Journal of Sociology, 117 (4), 1029-1072. http://dx.doi.org/10.1086/662649

Sinclair, M.T. (1991). Women, work and skill: economic theories and feminist perspectives. Dlm. Redcilft, N. \& Sinclair M.T. (pnyt.). Working women: international perspectives on labour and gender ideology, hlm, 1-24. London: Routledge.

Walby, S. (pnyt.). (1988). Gender segregation at work. Milton Keynes: Open University Press.

Walby, S. (1997). Gender transformations. London: Routledge.

\section{(cc) $\mathrm{BY}$}

This work is licensed under a Creative Commons Attribution 3.0 License. 